\title{
Out of Court Intellectual Property Right Dispute Resolution
}

\author{
Dewi Sulistianingsih ${ }^{1 *}$, Muhammad Shidqon Prabowo ${ }^{2}$
}

\begin{abstract}
${ }^{1}$ Department of Private and Commercial Law, Faculty of Law, Universitas Negeri Semarang, Semarang, Indonesia
${ }^{2}$ Department of Private and Commercial Law, Faculty of Law, Universitas Wahid Haysim, Semarang, Indonesia

*Corresponding author. Email: dewisulistianingsih21@ gmail.com
\end{abstract}

\begin{abstract}
Intellectual property disputes can include copyright, trademark, patent, industrial design rights, geographical indicative rights, integrated circuit layout design, and crop variety disputes. They require appropriate resolution and provide not only legal certainty but also provide justice and expediency for the disputing parties. The disputes can be resolved through litigation (court) and non-litigation (arbitration and alternative dispute resolution). Both the dispute resolutions, in and out of court, have their respective advantages and disadvantages. Out of court resolution becomes an alternative solution for the disputing parties knowing all of its advantages compared to dispute resolution through a court. The arbitration and alternative intellectual property right dispute resolutions have their own challenges considering that they are new compared to that carried out in court. The institutions that are assigned to handle intellectual property rights disputes in Indonesia are the Indonesian National Arbitration Board (BANI) and the Arbitration and Mediation Board of Intellectual Property Rights. Both of them have the authority to resolve intellectual property disputes out of court. Businesses in Indonesia currently do not fully understand the importance and urgency of resolving intellectual property rights disputes through BANI or BAM HKI. Moreover, the institutions still have limited authority to resolve intellectual property rights disputes.
\end{abstract}

Keywords: alternative dispute resolution, Arbitration, intellectual property, Indonesia

\section{INTRODUCTION}

Business people nowadays have prioritized intellectual property in their efforts to develop their companies. Their companies will be more established from asset support in the form of intellectual property. The intellectual property has been considered as the company's priority. A business needs to be supported by a powerful asset which has a longterm value in order to survive. It will always be a very important asset especially in the industrial revolution era. This condition makes more and more companies prioritize to develop their intellectual property to expand their companies.

Many companies consider an intellectual property as their main capital. An intellectual capital becomes a significant resource for many companies [1]. Since an intellectual property possesses a more profitable economic value than that of other tangible assets [2], it becomes an asset or a capital of the company. Intellectual property assets are often considered as the most valuable ones a company ever possesses. A developed company is one which is able to manage its assets and capitals properly and suitably.

The management of intellectual property as the company's asset is quite challenging as there must be appropriate strategies in utilizing it. It can be understood when a company does not have a maximum management of their intellectual property asset when there are disputes and violations towards the Intellectual Property Rights in Indonesia. Basically, every company will certainly need and implement an intellectual property. An inappropriate implementation of an intellectual property asset will lead to intellectual property disputes. The disputes may include those against other companies or the country as the holder of legal authority of the intellectual property rights.

Disputes are inevitable, yet nobody expects to encounter disputes. There is no party wishing to encounter disputes, but when they do, they should know how to resolve it fairly between the parties in dispute. A dispute is not a "taboo" thing to be discussed in the community since essentially it may occur anytime and it requires a prompt resolution. The dispute resolution is governed by law in order to create a betterment in the context of the fulfilment of interests between the legal subjects. Law lies in the stretch of activities of parties in disputes and infiltrates in every process of disputes to their resolutions.

Intellectual property rights disputes are part of civil disputes, which can be resolved using both court and out of court. Disputes over intellectual property rights can be submitted to the General Courts. It is one of the executors of the judicial power for those who seek justice in general. The judicial power within the General Courts is exercised by: Commercial Court while the judicial power in the General Courts environment culminates in the Supreme Court as the Supreme State Court. The Commercial Court's duty and authority are to examine, decide upon and resolve intellectual property rights disputes. at the first level.

The judiciary as an institution created by the legal system functions as a means of fair dispute resolutions through a simple, quick and low-cost judicial process. The implementation of the principles that the judicial process is carried out simply, quickly and with low costs is realized in 
achieving effective and efficient justice. However, the implications of the rapid development of economic and business activities are not matched by the court as a means of resolving disputes expected by the community. This is because judicial institutions that concretely carry out their duties to uphold law and justice when receiving, examining, adjudicating, and resolving any disputes submitted are considered as places for resolving disputes that are ineffective and inefficient. Until now the court is still trusted by the community as an institution to settle disputes including intellectual property disputes.

The procedural law that is used in trials that hear cases concerning IPR is to use the ordinary civil procedural law that has been used in the trials of cases in the general court environment. This is because in addition to IPR does not have its own procedural law. also disputes about IPRs are filed in commercial courts within the general court environment (district courts). Commercial Court is a Special Court within the scope of the General Court with cases which become the competence of the Commercial Court including regarding Bankruptcy and PKPU, Intellectual Property Rights, and the Deposit Insurance Agency.

Meanwhile, for settlement in the non-litigation or ADR, Indonesia has a governing regulation, is Act Number 30 of 1999 concerning Arbitration and Alternative Dispute Resolution. This law regulates the settlement of disputes or disagreements between the parties in a particular legal relationship that has entered into an arbitration agreement that expressly states that all disputes or disagreements arising or that may arise from the legal relationship will be resolved by arbitration or through alternative dispute resolution.

Generally, intellectual property rights disputes in Indonesia are settled through litigation. Nevertheless, there is also possibility for it to be carried out of court, especially since the establishment of the Arbitration Law and the ADR, has provided a clear legal basis for the parties to settle their intellectual property disputes through an arbitration and ADRs.

\section{RESEARCH METHODS}

This research is a legal research study focusing on intellectual property rights disputes resolved out of court as a legal issue. All data collected were analyzed using qualitative methods. The results of this study are presented in a descriptive analytical writing. This research was also conducted at the Indonesian National Arbitration Board (BANI) located in Jakarta and BANI Representative in Bandung.

\section{RESULTS AND DISCUSSION}

\subsection{IPR Dispute: Litigation Versus Non- Litigation}

Intellectual property right dispute resolution can be carried out through litigation mechanism, which is in court, while a non-litigation mechanism can be also carried out through an arbitration process and other alternative dispute resolutions. Intellectual property dispute resolutions through alternative dispute resolutions can be carried out in several ways: a mediation, a consultation, a conciliation, an expert judgment, and a negotiation. An intellectual property right dispute resolution, either through a litigation or a nonlitigation process, aims to provide certainty, justice, and benefits to both parties in dispute.

A litigation means a trial. A litigation (a court whose main duty is to resolve disputes by making a constitution such as making a verdict on an inheritance dispute, an unlawful conduct, etc. and minor duty is to anticipate disputes by making a court declaration, such as guardian and foster child decrees, etc. Based on the 1945 Constitution and its amendments, the court power represents the power of a sovereign nation to conduct a trial to enforce law and justice in line with Pancasila, in order to establish a constitutional state of Indonesia Republic. Indonesia's justice covers four areas which possess their respective authority to conduct hierarchic trials, namely the first level of justice, the level of appeal, and the level of appeal (the Supreme Court). The four scopes of the judiciary are the General Courts, Religious Courts, Military Courts, and State Administrative Courts.

The article 24 of the 1945 Constitution provides that any dispute resolution occurring among the public is carried out through a litigation. The judiciary as an institution established by the legal system functions as a means of fair dispute resolutions through a simple, quick and low-cost judicial process [3]. The implementation of the principles that the judicial process is carried out simply, quickly and with low costs is realized in achieving effective and efficient justice. However, the implications of the rapid development of economic and business activities are not matched with the judiciary as a means of resolving disputes expected by the public. This is because judicial institutions that concretely carry out their duties to uphold law and justice when receiving, examining, adjudicating, and resolving any disputes submitted are considered as places for resolving disputes that are ineffective and inefficient [4]. The settlement process through the court institution is an inefficient settlement process due to the length of the proceedings through the judiciary institution [5]. Even so the judiciary in Indonesia continues to strive to make improvements and continue to improve its performance. Until now the court is still trusted by the community as an institution to resolve disputes including intellectual property disputes.

An intellectual property dispute can be filed in the Commercial Court. The Commercial Court is a court whose authorities are to examine, hear, and sever closely intellectual property rights. An intellectual property dispute 
resolution as part of trade and business, requires legal certainty with a fast, simple and inexpensive legal process. Regarding civil disputes in the field of intellectual property, according to IPR regulations, the commercial court has been appointed as an IPR dispute resolution agency. Cases involving IPR disputes in the Commercial Court have been carried out in accordance with the procedures in the IPR regulation [6].

An intellectual property rights dispute resolution can be carried out through a non-litigation method. The nonlitigation path mentioned here is an arbitration and an alternative dispute resolution (ADR). The Alternative Dispute Resolution is an agency to resolve any dispute or dissent through a procedure agreed by the parties, namely resolving the dispute outside any judiciary body by means of consultation, negotiation, mediation, conciliation, or expert judgment. Arbitration is an alternative legal institution for organizers of disputes outside the court. An alternative dispute resolution has long been developed, both in the West and in the East. This is due to practical reasons such as the length of time taken when resolving disputes in court, considerable amount of costs to cultural reasons so that people prefer to resolve disputes outside the judiciary court [7].

Many economic needs require flexibility and a quick solution in resolving disputes which make alternative dispute resolution outside the judiciary body an unavoidable need, even as far as possible through a litigation because it is longer and more expensive, due to its procedural and bureaucratic matters [8]. Intellectual property rights disputes can be resolved by means of arbitration or ADR. Both are clearly stated in the legislation, both in the Copyright, Trademark, and Patent Acts.

In Indonesia, there is a growing trend to resolve disputes through a non-litigation since the enactment of Act Number 30 of 1999 concerning Arbitration and Alternative Dispute Resolution (Arbitration Act). This development is in line with the direction of globalization, in which a dispute resolution outside the judiciary body is opted by more and more business people when resolving their business disputes. In addition to its fast, efficient and complete characteristics, a non-litigation dispute resolution adheres to the principle of win-win solution, and it is not long-winded because there is no appeal and cassation institution. The costs of arbitration/ mediator/ consultant are also more measurable, because the process is faster. Another advantage of resolving disputes through a non-litigation is that its decisions are final and binding, in addition to their confidential nature, where the proceedings and arbitral award are not made public.

\subsection{Out Court Intellectual Property Rights}

Leaving disputes overdue late results in inefficient process of developments, declining productivity activities, unproductive business world, as well as hampering social welfare improvement. This situation is felt as a need to look for ways of resolving disputes that may arise, and which can be resolved quickly and informally, and can maintain the good name and trade interests of the disputing parties [9]. There have been many cases which occur related to intellectual property rights disputes in Indonesia, both in copyright, patent, industrial design rights, trade secret disputes, disputes in integrated circuit layout, disputes on plant varieties rights, trademark disputes, etc.

In general, a dispute resolution of Intellectual Property Rights can be resolved through two ways, namely: through a litigation process (court) or through an alternative path of dispute resolution. The in-court system of legal court resolution, is conventionally implemented by the Supreme Court (MA) and the judicial bodies under it. Out-court system is a system of resolving legal disputes outside the court [10]. The dispute resolutions through a judicial body are those involving parties in dispute that produce a decision which binds both parties, while resolutions through alternative channels of dispute resolution are regulated in article 1 point 10 of the Arbitration Law and Alternative Dispute Resolution where it is stipulated that "Alternative dispute resolution is dispute resolution institutions whose procedures and mechanisms are determined by the parties". An in-court dispute resolution is done by filing a civil suit in the commercial court. The commercial court acquire the authority or competence to settle several disputes in the field of intellectual property rights as determined in the provisions of the IPR legislation [11]. An arbitration can also be chosen as a medium for intellectual property dispute resolution. Besides negotiation, conciliation and mediation are some alternative forms of dispute resolution that can be chosen in intellectual property dispute resolution [12].

Dispute resolutions through Arbitration and Alternative Dispute Resolution (ADR) in Indonesia were initially limited to trade disputes only, but currently dispute resolution through arbitration and APS can be used to resolve civil disputes, both general and special civil disputes. Intellectual property rights disputes can be resolved by means of arbitration or APS. Both are clearly stated in the legislation, both in the Copyright Act, Trademark Act, and Patent Act.

In Indonesia, there has an increasing interest in resolving disputes through an arbitration since the enactment of Act Number 30 of 1999 concerning Arbitration and Alternative Dispute Resolution (Arbitration Act). This development is in line with the direction of globalization, where dispute resolution out of court has become the choice of business people to resolve their business disputes. In addition to its fast characteristic, it is efficient and complete. The arbitration adheres to the principle of win-win solution, and is not long-winded because there is no appeal and cassation institution. The cost of arbitration is also more measurable, because the process is faster. Another advantage of arbitration is that its decision is final and binding, in addition to its confidential nature [13], since the proceedings and arbitral award are not made public.

A dispute resolution is conventionally carried out through the court (litigation system), but it is further developed into a dispute resolution carried out outside the court due to a dissatisfaction with the efforts to settle the dispute through a court [14]. An out-court dispute resolution is an alternative that is worth considering, especially by the business community because it is in accordance with the "character/ nature" of the business, which is characterized by a win-win solution [15], a complete, simple, fast, not bureaucratic, practical, and inexpensive conflict resolution [16]. In the 
process of resolving disputes outside the court, the parties can freely determine their own procedure, litigation, location of the court, and can monitor the process directly. The parties can freely make decisions or determine whether in the resolution process a model/ form of resolution is found that is more beneficial to both parties so that they can immediately establish a truce. Out-of-court dispute settlement system is a dispute resolution system that can be adjusted to the wishes of the parties (tailor made system). Besides that, it is suitable with the culture of Indonesian people who have the principle of deliberation and consensus in all aspects of life including in dispute resolutions.

In Indonesia, there are two institutions that can resolve disputes over intellectual property rights outside the court, namely the Indonesian National Arbitration Board (BANI) and the Arbitration and Intellectual Property Rights Mediation Board (BAM HKI). The Indonesian Chamber of Commerce and Industry (KADIN) initiated the establishment of the Indonesian National Arbitration Board (BANI) on 3 December 1977 [17]. Although intellectual property rights disputes can be resolved through a nonlitigation (out court), in reality, the resolution of IPR disputes carried out outside the court is still low.

There haven't been many intellectual property rights disputes which are resolved through a non-litigation (out court). The Indonesian National Arbitration Board (BANI) has settled only 10 intellectual property rights disputes over the past 10 years. The Arbitration and Mediation Board of Intellectual Property Rights (BAM HKI). The factors of the tendency to resolve IPR disputes more through litigation are due to: (1) Lack of socialization about arbitration and mediation; (2) Not many parties/ entrepreneurs know about BANI and BAM IPR in the resolution of IPR disputes; (3) There needs to be an agreement to resolve disputes over intellectual property rights outside the court (through BANI or BAM HKI); (4) Lack of culture of dispute resolution outside the court. Based on this, it is suggested that there must be more socialization about arbitration and mediation, including to business people in Indonesia.

The intellectual property rights disputes resolutions through non-litigation or outside the court can be said to have not been implemented optimally, as evidenced by the lack of intellectual property rights disputes registered at the arbitration institution and alternative dispute resolution. The intellectual property rights dispute resolution is still currently mostly carried out in the court.

Such conditions lead to the necessity to carry out better and more proper socialization and understanding of the parties involved in intellectual property rights, like entrepreneurs, rights owners, and rights and license holders. There must be the best solution if a dispute occurs and the resolution must uphold justice with benefits based on a win-win solution.

\section{CONCLUSION}

The mechanism for resolving disputes outside the court is considered to be more effective, efficient, fast and low cost as well as benefit both parties in disputes (win-win solution). The intellectual property rights dispute resolution is considered better carried out through a non-litigation or through mediation institutions because it is faster and cheaper. However, in its implementation, there are still many parties involved in an intellectual property dispute who resolve their disputes through a litigation.

The authority of BANI and BAM HKI in resolving disputes especially intellectual property disputes needs to be studied in depth. This is based on the role of BANI and BAM HKI in resolving intellectual property disputes which are new to Indonesia. How effective and what is faced by BANI and BAM HKI in the course of intellectual property dispute resolution needs to be analyzed properly.

BANI and BAM HKI provide solutions to resolve intellectual property disputes that make BANI and BAM HKI the choice of parties in the dispute. There haven't been many intellectual property rights disputes resolution carried out through BANI, because intellectual property rights disputes are mostly still carried out through the court. BANI as an institution that receives registration of intellectual property rights disputes awaits registration of the disputing parties. There needs to be awareness of the disputing parties to resolve their intellectual property rights negotiations through BANI. Although BANI has been established since 1977, there are not many business people who understand the importance and urgency of settling their intellectual property disputes through non-litigation channels.

\section{REFERENCES}

[1] Sullivan, P. H. (1999). Profiting from intellectual capital. Journal of Knowledge Management, 3(2), 132143.

[2] Kusnadi, K. (2013). Audit Hak Kekayaan Intelektual Sebagai Bagian Pengelolaan Risiko Kerugian Bisnis Bagi Perusahaan. LAW REFORM, 9(1), 70-88.

[3] Efa Laila Fakhriah. (2013). Mekanisme Small Claims Cortt Dalam Mewujudkan Tercapainya Peradilan Sederhana, Cepat, Dan Biaya Ringan. Mimbar Hukum-Fakultas Hukum Universitas Gadjah Mada, 25(2), 258-270.

[4] Indriati Amarini. (2017). Penyelesaian Sengketa Yang Efektif Dan Efisien Melalui Optimalisasi Mediasi Di Pengadilan. Kosmik Hukum, 16(2).

[5] Netty Herawati. (2011). Implikasi Mediasi Dalam Perkara Perdata di Pengadilan Negeri Terhadap Asas Peradilan Sederhana, Cepat, dan Biaya Ringan. Perspektif, 16(4), 227-235.

[6] Henry Donald (2017). Penyelesaian Sengketa Hak Kekayaan Intelektual Melalui Acara Cepat. Jurnal Penelitian Hukum De Jure, 17(1), 74-91.

[7] Moch. Faisal Salam, Penyelesaian Sengketa Bisnis Secara Nasional dan Internasional, (Bandung: Mandar Maju, 2007), halaman 140. 
[13] Nasution, A. R. (2015). Keberadaan Badan Arbitrase Nasional Indonesia sebagai Pilihan Penyelesaian Sengketa Hutang Piutang. Premise Law Journal, 11, 1-15.

[14] Sudjana, S. (2018). Efektivitas dan Efisiensi Penyelesaian Sengketa Kekayaan Intelektual melalui Arbitrase dan Mediasi berdasarkan Undang-Undang Nomor 30 Tahun 1999. Ajudikasi: Jurnal Ilmu Hukum, 2(1), 81-96.

[15] Faisal, M. (2017). Peranan Badan Arbitrasi Nasional Indonesia dalam Menyelesaikan Sengketa Bisnis di Indonesia. Jurnal Jatiswara, 30(2), 279-289.

[11] Karwur, I. G. F. (2019). Pengaturan Hukum Tentang Kewenangan dan Prosedur Penyelesaian Sengketa di Bidang Hak atas Kekayaan Intelektual (HAKI). LEX PRIVATUM, 6(8), 90-101.

[12] Dewi, G. P., \& Putra, D. N. R. A. Tinjauan Yuridis Terhadap Mediasi Sebagai Alternatif Penyelesaian Sengketa Kekayaan Intelektual. Kertha Wicara: Journal Ilmu Hukum, 8 (3), 1-15.
[16] Situmorang, M. (2017). Pelaksanaan Putusan Arbitrase Nasional di Indonesia. Jurnal Penelitian Hukum De Jure, 17(4), 309-320

[17] Sudini, L. P., \& Arini, D. G. D. (2017). Eksistensi Badan Arbitrase Nasional Indonesia (BANI) Dalam Penyelesaian Sengketa Perusahaan. Jurnal Notariil, 2(2), 141-148. 